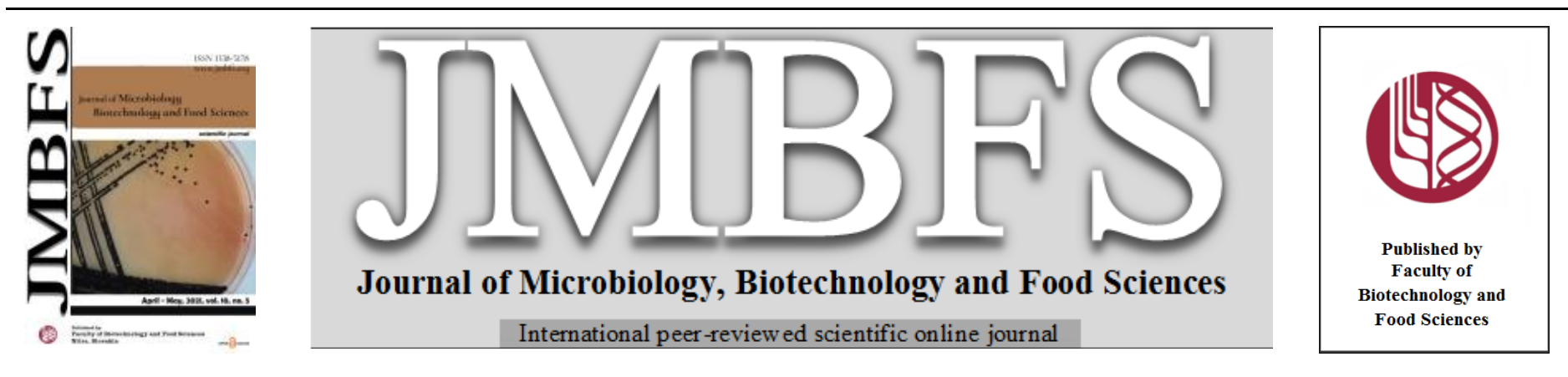

\title{
MORPHOLOGICAL AND GENETIC DIVERSITY ANALYSIS IN CALENDULA (CALENDULA OFFICINALIS L.) INFLUENCED BY MUTAGENIC EFFECT OF COLCHICINE
}

\author{
Ahmed A.M. Yassein ${ }^{2}$, Abd Allah H.A. Hassen ${ }^{2}$,Ebtsam M. Abdel-Alah ${ }^{2}$, Shoukry M. Selim ${ }^{2}$
}

Address(es): Ahmed A.M. Yassein,

${ }^{1}$ Fayoum University, Faculty of Agriculture, Genetics Department, 63514, Fayoum, Egypt.

${ }^{2}$ Fayoum University, Faculty of Agriculture, Horticulture Department, 63514, Fayoum, Egypt.

*Corresponding author: aay00@fayoum.edu.eg

https://doi.org/10.15414/jmbfs.3392

\section{ARTICLE INFO}

Received 4. 7. 2020

Revised 24. 11.2020

Accepted 3. 12. 2020

Published 1. 4. 2021

Regular article

open $\partial_{\text {AcCESS }}$

\begin{abstract}
Calendula officinalis L. (pot marigold) is one of the main aromatic and medicinal plants with many uses in food and medicines. This study was carried out to demonstrate the efficiency of six colchicine concentrations $(0.025,0.05,0.1,0.2,0.4$ and 0.8 per cent, w/v) for Calendula improvement and induction of genetic variation. Colchicine treatments had a positive effect on the number of branches/plant, number of inflorescences, fresh and dry weight of inflorescences, inflorescence diameter, total soluble carbohydrates and $\beta$-carotene except for plant height, while seed germination and plant height were reduced. Estimation of heritability, genetic advance, genetic variability and selection of superior genotypes will be an important object in crop breeding and genetic improvement programs, and selection of genotypes with higher desirable characters. Heritability was high and ranged from 48.64 to 90.81 , respectively (inflorescence diameter and plant height, respectively). Molecular markers based on a RAPD-PCR study elucidate the classification of induced Calendula mutants into two clusters. The coefficient of genetic diversity was estimated at $30 \%$. A combination of morphological and physiological responses with molecular data contained in the various colchicine treatments illustrated the utility of RAPD-PCR as a method for identifying useful mutants and could be used to detect the colchicine effect significantly. Findings recommend the 0.05 per cent colchicine for efficient breeding calendula mutation and genetic improvement.
\end{abstract}

Keywords: Calendula, Colchicine, RAPD-PCR, Genetic diversity, Heritability

\section{INTRODUCTION}

Calendula officinalis L.(Asteraceae) is known as pot marigold, and it is an annual herb with yellow to orange inflorescences, originally to the Mediterranean region (Ramos et al., 1988). C. officinalis is used in drugs, medicines, decoration and food (Ramos et al. 1988; Della-loggia et al., 1994). Mutation breeding is one of plant breeding methods successfully conducted to enhance genetic diversity by means of crop improvement (Kharkwal and Shu 2009). Colchicine is poisonous alkaloid and is known as chemical mutagenic. More than studies suggested the effect of colchicine on plant as a mutagen, which prevents microtubules form forming and contributes to mutagenic effects (Pickens $\boldsymbol{e t}$ al., 2006), and mutant plants typically grow shorter stems and high inflorescences (Pickens et al., 2006). The application of various colchicine concentrations had a significant effect on content of $\beta$-carotene in plants, e.g. in Sesamum indicum (Nura et al., 2013) and Echinacea purpurea (Abdoli et al., 2013). Broad sense heritability and genetic advance were important for plant breeding programme (Herbert $\boldsymbol{e t}$ al. 1955).

In addition to the phenotypic traits, the mutagenic effects can be accurately assessed using DNA molecular marker techniques used to identify and evaluate genetic diversity between plant species, genotypes and cultivars (El-Nashar and Ammar 2016; Soubra et al., 2018). The goal of the present study was to assess the efficiency of different concentrations of colchicine in induction of new agronomic, chemical and yield components of Calendula mutant plants. Estimate heritability, genetic advance, genotypic coefficient of variability (GCV) and the phenotypic coefficient of variability (PCV). Genetic diversity evaluation of induced mutants controlled RAPD outcomes.

\section{MATERIAL AND METHODS}

Experimental layout

Local of pot marigold (C. officinalis) accession seeds, kindly provided by Aromatic and Medicinal Plant farmer, Beni Suef Governate, Egypt. During three successive seasons (2015/2016, 2016/2017 and 2017/2018), field experiments were carried out at a private farm, Beni Suef Governorate. Seeds were sown with peat-moss in plastic trays and incubated in kindergartens. After 45 days the grown seedlings were individually transplanted in plastic bags filled with claying soil.

\section{Effect of colchicine on seed germination}

Calendula seeds were germinated in petri dishes with filter paper for 2 weeks. NaOCL 5\% was used to surface sterilized with for 5 minutes prior to planting to avoid fungal invasion and then washed immediately with distilled water. For control and each treatment four replications of twenty five seeds were placed in 12-cm Petri dishes and then incubated with $25{ }^{\circ} \mathrm{C}$ for 2 weeks. Seeds were checked after 2 days for germination (radical length of greater than $5 \mathrm{~mm}$ was considered germination and were counted) and filter paper was remoistened as needed as described by (Eberle et al. 2014; Kouchebagh et al. 2015).

\section{Colchicine treatments}

The transplants were treated with colchicine concentrations at $(0.0,0.025,0.05$, $0.1,0.2,0.4$ and $0.8 \%, \mathrm{w} / \mathrm{v})$. Samples of $\mathrm{M}_{1}$-plants from each treatment were obtained. Additionally, $\mathbf{M}_{1}$-generation (first season) seeds were replanted for the next year's $\mathrm{M}_{2}$-generation. Similarly, seeds obtained from the $\mathbf{M}_{2}$-generatin (second season) have been replanted for generation $\mathrm{M}_{3}$

\section{Vegetative growth characters}

The three $\mathrm{M}$ generations were assessed for plant height $(\mathrm{cm})$, number of branches/plant, number of inflorescences/plant, inflorescence diameter $(\mathrm{cm})$, fresh and dry weight of inflorescences/plant (g). 
Total soluble carbohydrates and $\beta$-carotene content

Both total soluble carbohydrates (\%) (Dubois et al., 1956) and $\beta$-carotene $\mathrm{mg}^{-1}$ DW (A.O.A.C. 1970) were determined with the Last collection dried inflorescence.

\section{DNA extraction and quality confirmation}

At the 3-4 leaves stages leaf tissues were collected from the plants (Hyam 1998) Freeze-drying lyophilized the leaves, and then frozen in $-80^{\circ} \mathrm{C}$ freezer until use The tissue samples were ground by applying liquid nitrogen to a powder. Genomic DNA extraction was carried out using $0.1 \mathrm{~g}$ bulked tissue collected from individual plants equivalent weights of freeze-dried leaf samples. The bulked tissues were put into tubes of $2 \mathrm{ml}$ eppendorf. Acetyltrimethyl ammonium bromide (CTAB) method (Dellaporta et al 1983) has been used in isolation of DNA. In the TE buffer, the extracted DNA was re-suspended. Samples of $5 \mu$ of isolated DNA used a $0.8 \%$ agarose gel in TAE buffer, as defined by the sample, to assess the quality of DNA (Sambrook et al., 2006).

\section{RAPD-PCR reaction}

Reaction using extracted DNA, oligonucleotide primers (Table 1) was used for amplification to standardize the PCR conditions. In a DNA Thermo cycler the reactions were done. Each $25 \mu l$ reaction volume contained 12.5 $\mu l$ Master Mix (one step $\mathrm{PCR}^{\mathrm{TM}}$ ), $2 \mu l$ of primer, $3 \mu l$ of genomic DNA (about $50 n g / \mu \mathrm{l}$ ) and 7.5 $\mu l$ of sterile deionized water. In this study, RAPD primers that have been synthesized by Invitrogen, Biotechnology Co. Ltd. (USA) were used (Table 1). PCR reactions carried out with following conditions: initial denaturation step at $94^{\circ} \mathrm{C}$ for $5 \mathrm{~min}$, then followed by 35 cycles of amplification at $94^{\circ} \mathrm{C}$ for $1 \mathrm{~min}$ $36^{\circ} \mathrm{C}$ for $1 \mathrm{~min}, 72^{\circ} \mathrm{C}$ for $1 \mathrm{~min}$, followed by a final extension at $72^{\circ} \mathrm{C}$ for $10 \mathrm{~min}$ were performed using thermal cycler 2720 (Applied Biosystems, USA). The PCR products were separated into a $1.2 \%$ agarose gel prepared with incorporated ethidium bromide by the $1 \mathrm{X}$ TAE (40 mM Tris-acetate, $1 \mathrm{mM}$ EDTA, pH 8.3).

Table 1 List of primers were used and their nucleotide sequences.

\begin{tabular}{lll}
$\mathbf{N o .}$ & Primer code & Primers sequence (5'-3') \\
\hline $\mathbf{1}$ & OPA-1 & -5 CAGGCCCTTC 3- \\
\hline $\mathbf{2}$ & OPA-2 & -5 TGCCGAGCTG 3- \\
\hline $\mathbf{3}$ & OPA-3 & -5 AGTCAGCCAC 3'- \\
\hline $\mathbf{4}$ & OPA-4 & -5 AATCGGGCTG 3'- \\
\hline $\mathbf{5}$ & OPA-5 & -5 AGGGGTCTTG 3- \\
\hline $\mathbf{6}$ & OPA-6 & -5 GCTCCCTGAC 3- \\
\hline $\mathbf{7}$ & OPA-7 & -5 GAAACGGGTG 3- \\
\hline $\mathbf{8}$ & OPA-8 & -5 GTGACGTAGG 3- \\
\hline $\mathbf{9}$ & OPA-9 & -5 GGGTAACGCC 3- \\
\hline $\mathbf{1 0}$ & OPA-10 & -5 GTGATCGCAG 3- \\
\hline $\mathbf{1 1}$ & OPC-1 & -5 TTCGAGCCAG 3- \\
\hline $\mathbf{1 2}$ & OPC-2 & -5 GTAAGGCGTC 3- \\
\hline $\mathbf{1 3}$ & OPC-3 & -5 GGGGGTCTTT 3- \\
\hline $\mathbf{1 4}$ & OPC-6 & -5 GAACGGACTC 3'- \\
\hline $\mathbf{1 5}$ & OPC-7 & -5 GTCCCGACGA 3'- \\
\hline $\mathbf{1 6}$ & OPC-8 & -5 TGGACCGCTG 3'- \\
\hline
\end{tabular}

Table 3 Effect of colchicine on plant height $(\mathrm{cm})$, No. branches/plant, No. inflorescences/plant, inflorescence diameter $(\mathrm{cm})$, inflorescence fresh and dry weight ( $\mathrm{g})$, total soluble carbohydrates $(\%), \beta$-carotene $\left(\mathrm{mg}^{-1} \mathrm{DW}\right)$ of $C$. officinalis plant (mean of 3 seasons).

\begin{tabular}{|c|c|c|c|c|c|c|c|c|}
\hline Colchicine & $\begin{array}{c}\text { plant } \\
\text { height } \\
\text { (cm) }\end{array}$ & $\begin{array}{c}\text { No. } \\
\text { branches/plant }\end{array}$ & $\begin{array}{c}\text { No. } \\
\text { Inflorescences/ } \\
\text { plant }\end{array}$ & $\begin{array}{l}\text { inflorescence } \\
\text { diameter }(\mathrm{cm})\end{array}$ & $\begin{array}{c}\text { fresh weight } \\
\text { (g) }\end{array}$ & $\begin{array}{c}\text { dry weight } \\
\text { (g) }\end{array}$ & $\begin{array}{c}\text { total soluble } \\
\text { carbohydrate } \\
\left(\mathrm{mg}^{-1} \mathrm{DW}\right)\end{array}$ & $\begin{array}{c}\beta \text {-carotene } \\
(\%)\end{array}$ \\
\hline Control & $58.97^{\mathrm{A}}$ & 5.89 & $45.53^{\mathrm{B}}$ & $6.95^{\mathrm{B}}$ & 6.15 & $1.03^{\mathrm{D}}$ & $12.72^{\mathrm{B}}$ & $0.41^{\mathrm{B}}$ \\
\hline $\mathbf{0 . 0 3 \%}$ & $55.28^{\mathrm{AB}}$ & 6.61 & $49.03^{B}$ & $6.83^{B}$ & 6.23 & $1.06^{\mathrm{CD}}$ & $12.99^{\mathrm{B}}$ & $0.45^{\mathrm{A}}$ \\
\hline $0.05 \%$ & $51.44^{\mathrm{BC}}$ & 8.88 & $58.19^{A}$ & $7.78^{\mathrm{A}}$ & $7.89^{A}$ & $1.32^{\mathrm{A}}$ & $14.12^{\mathrm{A}}$ & $0.45^{\mathrm{A}}$ \\
\hline $0.10 \%$ & $46.67^{\mathrm{CD}}$ & 8.03 & $55.33^{A}$ & $6.70^{\mathrm{B}}$ & $7.22^{\mathrm{B}}$ & $1.22^{\mathrm{B}}$ & $13.62^{\mathrm{AB}}$ & $0.44^{\mathrm{AB}}$ \\
\hline $0.20 \%$ & $46.81^{\mathrm{CD}}$ & 7.78 & $53.78^{\mathrm{A}}$ & $6.77^{\mathrm{B}}$ & $6.43^{C}$ & $1.15^{\mathrm{B}}$ & $13.36^{\mathrm{AB}}$ & $0.44^{\mathrm{AB}}$ \\
\hline $0.40 \%$ & $42.25^{\mathrm{D}}$ & 7.16 & $49.83^{\mathrm{B}}$ & $6.93^{B}$ & 6.11 & $1.05^{\mathrm{CD}}$ & $12.99^{\mathrm{B}}$ & $0.43^{\mathrm{AB}}$ \\
\hline $0.80 \%$ & $39.22^{\mathrm{D}}$ & 6.56 & $47.42^{\mathrm{B}}$ & $6.56^{\mathrm{B}}$ & $5.47^{\mathrm{C}}$ & $1.02^{\mathrm{D}}$ & $12.89^{\mathrm{B}}$ & $0.42^{\mathrm{B}}$ \\
\hline
\end{tabular}

Legend: Means denoted by a different letter indicate significant difference between treatments $p \leq 0.05$.

\section{Number of branches/plant}

Application of different concentrations of colchicine increased branches/plant numbers Table (3). Moderate concentration, as opposed to other treatments and control, 0.05 per cent had the most effect in terms of number of branches per plant. The maximum number of branches/plant recorded was 8.8 from plants received 0.05 per cent colchicine. The findings generally showed that the comparative analysis between treated and control plants showed significant differences in the number of branches. This result may be due to high vigour

\section{RAPD-PCR Analysis}

RAPD-PCR Analysis was used to evaluate the DNA samples' genetic diversity Hence, visually scored as present (1) or absent (0) for the reproducible, polymorphic and monomorphic bands. Also faint reproducible RAPD bands were scored as in the program of (NTSYSpc, ver. 2.1). For each primer, the total number of bands per line was recorded and the percentages of polymorphic band were determined.

\section{Statistical analysis}

The experimental design used was randomized complete blocks with three replications and data analysis was performed by (SPSS 25 software). Duncan's multiple range tests were outline to assess the significance between treatments $p \leq 0.05$.

\section{RESULTS AND DISCUSSION}

\section{Effect of colchicine on seed germination}

With colchicine use, the percentage of seed germination has been reduced. The highest rates were $98 \%$ and $88 \%$ respectively, from control and low concentration of colchicine, $(0.025 \%)$. Low germination rate was observed at high concentrations of 0.4 and 0.8 per cent colchicine (Table 2). These findings are in agreement with various reports in ornamental plants which confirm the reduction of germination with colchicine application (Ramos et al., 1988, Dellaloggia et al., 1994, Abdoli et al., 2013).

Table 2 Effect of colchicine on seed germination (\%).

\begin{tabular}{lc}
\hline Colchicine & Seed germination (\%) \\
\hline Control & $98.00^{\mathrm{A}}$ \\
\hline $\mathbf{0 . 0 3 \%}$ & $88.00^{\mathrm{B}}$ \\
\hline $\mathbf{0 . 0 5 \%}$ & $68.00^{\mathrm{C}}$ \\
\hline $\mathbf{0 . 1 0 \%}$ & $36.00^{\mathrm{D}}$ \\
\hline $\mathbf{0 . 2 0 \%}$ & $32.00^{\mathrm{D}}$ \\
\hline $\mathbf{0 . 4 0 \%}$ & $12.00^{\mathrm{E}}$ \\
\hline $\mathbf{0 . 8 0 \%}$ & $12.00^{\mathrm{E}}$ \\
\hline
\end{tabular}

Legend: Means denoted by a different letter indicate significant difference between treatments $\mathrm{p} \leq 0.05$

\section{Vegetative growth characters}

\section{Plant height}

Results in Table (3) indicate that colchicine treatment at all concentrations decreased plant height in a negative way. It is found, however, that plant height is associated with rising concentration of colchicine. For plants treated with 0.8 per cent colchicine, the shortest height was $39.22 \mathrm{~cm}$.

These results may be due to negative reflection on plant height of the treatment desires with colchicine effect on cells division, and enlargement cells in plant organs. Similar results were reported by (El-Nashar and Ammar 2016; Estaji et al., 2017; Kushwah et al., 2018; Samatadze et al., 2019). They found the maximum height of plants was observed in the controls. Plant height was reduced maximum height of plants was observed in the contrc
linearly by enhancing concentration of colchicine. growth differentiated by Calendula plants especially branching ratio under moderate levels of colchicine but with increasing concentration of colchicine, the number of branches decreased. Such findings are compatible (Amiri et al., 2010) with Datura stramonium, (Yassein and Aly 2014) with Brassica napus, and (ElNashar and Ammar 2016) with $C$. officinalis. They reported that when colchicine was applied the number of branches per plant increased. This may be due to the influence of colchicine concentrations on high apical meristems development for the auxiliary Calendula plant branches. The maximum number 
of branches may be due to regular colchicine supply which increased vegetative growth.

\section{Number of inflorescences/plant}

Table (3) showed that with all the different concentrations of colchicine the number of inflorescences/plant was increased. The maximum number of inflorescences (58.19) was reported by 0.05 per cent colchicine. The moderate concentration of colchicine, 0.05 and 0.1 per cent observed high inflorescences number than low and high concentration rates. There appears to be correlations between number of branches and number of inflorescences, so with increasing number of branches due to consuming more colchicine causes an increasing number of inflorescences. This may be due to Calendula plants distinguishing high vigour growth especially branching ratio under moderate levels of colchicine but with increasing concentration of colchicine, the number of inflorescences decreased.

These findings are in line with (Hannweg et al., 2013) on Crocosmia aurea and (El-Nashar and Ammar 2016) on C. officinalis. They found that number of inflorescences/plant in most moderate treatments was increased by treating plants with colchicine relative to control plants.

\section{Diameter of inflorescence}

Results provided in Table (3) show that colchicine significantly increased the diameter of inflorescences using 0.05 per cent relative to control, and measured $7.78 \mathrm{~cm}$. This result revealed that inflorescences diameter of Calendula plants increased as concentration rate of colchicine increased and reached its peak values at 0.05 per cent. Similar results were reported by various authors as (Zhang et al., 2016) on Trollius chinensis (Wang et al., 2017) on Fagopyrum tataricum and (El-Nashar and Ammar 2016) on C. officinalis. They found that colchicine treatments had a positive and significant effect on diameter of inflorescences compared to untreated plants.

\section{Fresh and Dry weight of inflorescence}

Results in Table (3) showed that the moderate concentrations of colchicine had a positive impact on fresh and dry inflorescence weight, especially 0.05 per cent, with the highest significant records on fresh and dry weight, respectively with 7.89 and $1.32 \mathrm{~g}$. These findings comply with (El-Nashar and Ammar 2016) on
C. officinalis, (Wang et al., 2017) on F. tataricum, and (Kushwah et al., 2018) on $C$. carinatum.

\section{Total soluble carbohydrates}

Results presented in Table (3) clarified that colchicine treated plants increased the total soluble carbohydrates content compared with untreated plants, especially at 0.05 per cent with $14.12 \%$. Similar results (Estaji et al., 2017) reported on $S$. leriifolia and (Abdoli et al., 2013) E. purpurea.

\section{$\beta$-carotene pigment content}

Data tabled in Table (3) showed that the content of $\beta$-carotene increased slightly w moderate levels of colchicine. The highest significant content of $\beta$-carotene was $0.45 \mathrm{~m}$ DW derived from 0.05 per cent colchicine treated plants. Different results (Nura et a 2013), published on $S$. indicum and E. purpurea (Abdoli et al., 2013). They concluded th the amount of $\beta$-carotene inflorescence was increased as a result of an increased treatment colchicine relative to control plants.

\section{Heritability and Genetic Variability}

In trying to determine the variability in agronomic and yield components, which responsible for yield variation between different cultivars, heritable components must determined. Genetic advances and heritability estimates are important preliminary criteria any plant breeding program and the heritable variation is powerful for plant gene improvement. Table (4) describes the genotypic coefficient of variability (GCV), phenotypic coefficient of variability (PCV), broad sense heritability and genetic advance percentage of mean for traits. The GCV values for plant height, No. branches, fresh and weight were moderate $(14.18,13.85,12.05$ and 9.76 , respectively). The remaining featur registered low GCV values. The heritability of broad sense for all traits has been calculat The estimated high variation in heritability between traits ranged from 48.64 to $90.81 \mathrm{p}$ cent in plant height (Table 4). High heritability was observed for plant height along w high genetic advance, estimation of genetic advance is effective as selection criterion wh viewed in combination with heritability estimates (Herbert $\boldsymbol{e t}$ al., 1955). High estimates heritability for plant height, fresh weight, No. inflorescences, dry weight and No. branch suggest a strong selection response in these traits. Various authors reported similar resu (Rahim et al., 2010; Eshghi et al., 2012; Yassein and Aly 2014).

Table 4 Estimates of genetic parameters

\begin{tabular}{|c|c|c|c|c|c|c|c|c|}
\hline $\begin{array}{l}\text { Genetic } \\
\text { parameters }\end{array}$ & $\begin{array}{l}\text { Plant } \\
\text { height }\end{array}$ & $\begin{array}{c}\text { No. } \\
\text { branches }\end{array}$ & $\begin{array}{c}\text { No. } \\
\text { Inflorescences }\end{array}$ & $\begin{array}{l}\text { inflorescence } \\
\text { diameter }\end{array}$ & $\begin{array}{l}\text { inflorescence } \\
\text { fresh weight }\end{array}$ & $\begin{array}{l}\text { inflorescence } \\
\text { dry weight }\end{array}$ & $\begin{array}{l}\text { total soluble } \\
\text { carbohydrate }\end{array}$ & $\beta$-carotene \\
\hline$h^{2}$ & 90.806 & 80.871 & 85.52 & 48.643 & 87.077 & 84.701 & 65.317 & 51.628 \\
\hline Gs & 27.839 & 25.158 & 16.53 & 7.0851 & 23.165 & 18.497 & 5.7007 & 4.539 \\
\hline GCV & 14.182 & 13.58 & 8.68 & 4.9314 & 12.051 & 9.7563 & 3.4241 & 3.0665 \\
\hline PCV & 14.882 & 15.101 & 9.38 & 7.0706 & 12.914 & 10.601 & 4.2368 & 4.2678 \\
\hline
\end{tabular}

Legend: Heritability $h^{2}$, Genetic advance (Gs), Genetic coefficient variance (GCV), and phenotypic coefficient variance (PGV) for plant height, No. branches/plant, No. inflorescences, inflorescence diameter, fresh and dry weight of inflorescences, total soluble carbohydrates and $\beta$-carotene content.

\section{RAPD Conditions for Amplification}

estimate phylogenetic relationships. RAPD-PCR technique was used to characte calendula genotypes as powerful tool for detecting of genetic differences, requiring simp

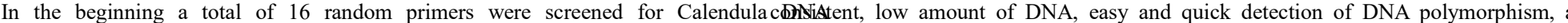

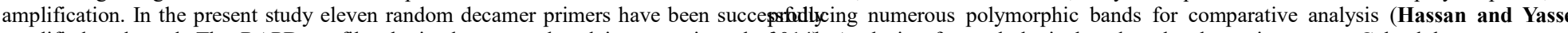

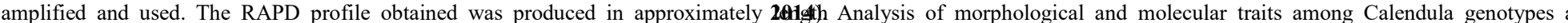

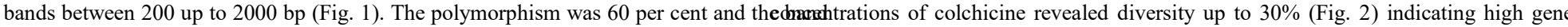

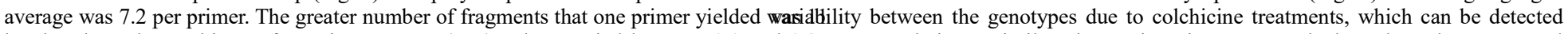

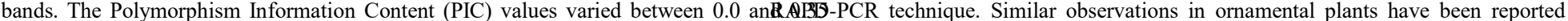

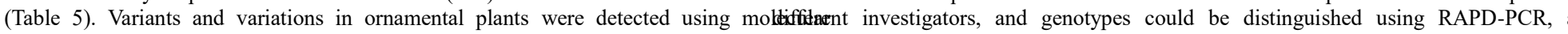

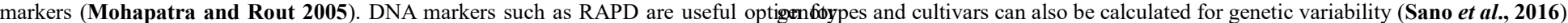
genetic diversity assessment. For plant breeding and genetics studies (Mikhaǐlovskiǐ et al., 2007), Genetic variations can be used to identify species, genotypes and cultivar and to

Table 5 Characterization of selected RAPD primers with C. officinalis

\begin{tabular}{lllll} 
Primer & Amplified products & Polymorphic product & $\boldsymbol{\%}$ polymorphism & $\begin{array}{l}\text { Polymorphism Information Content } \\
\text { values }\end{array}$ \\
\hline OPA1 & 5 & 3 & 60 & 0.277 \\
\hline OPC2 & 4 & 0 & 0 & 0 \\
\hline OPC3 & 9 & 8 & 89 & 0.345 \\
\hline OPA4 & 9 & 8 & 89 & 0.336 \\
\hline OPA5 & 9 & 7 & 78 & 0.254 \\
\hline OPA6 & 6 & 2 & 33 & 0.109 \\
\hline OPA7 & 5 & 2 & 40 & 0.131 \\
\hline OPA8 & 11 & 6 & 55 & 0.23 \\
\hline OPA9 & 8 & 5 & 63 & 0.224 \\
\hline OPA10 & 9 & 8 & 89 & 0.318 \\
\hline OPC2 & 7 & 0 & 0 & 0 \\
\hline
\end{tabular}



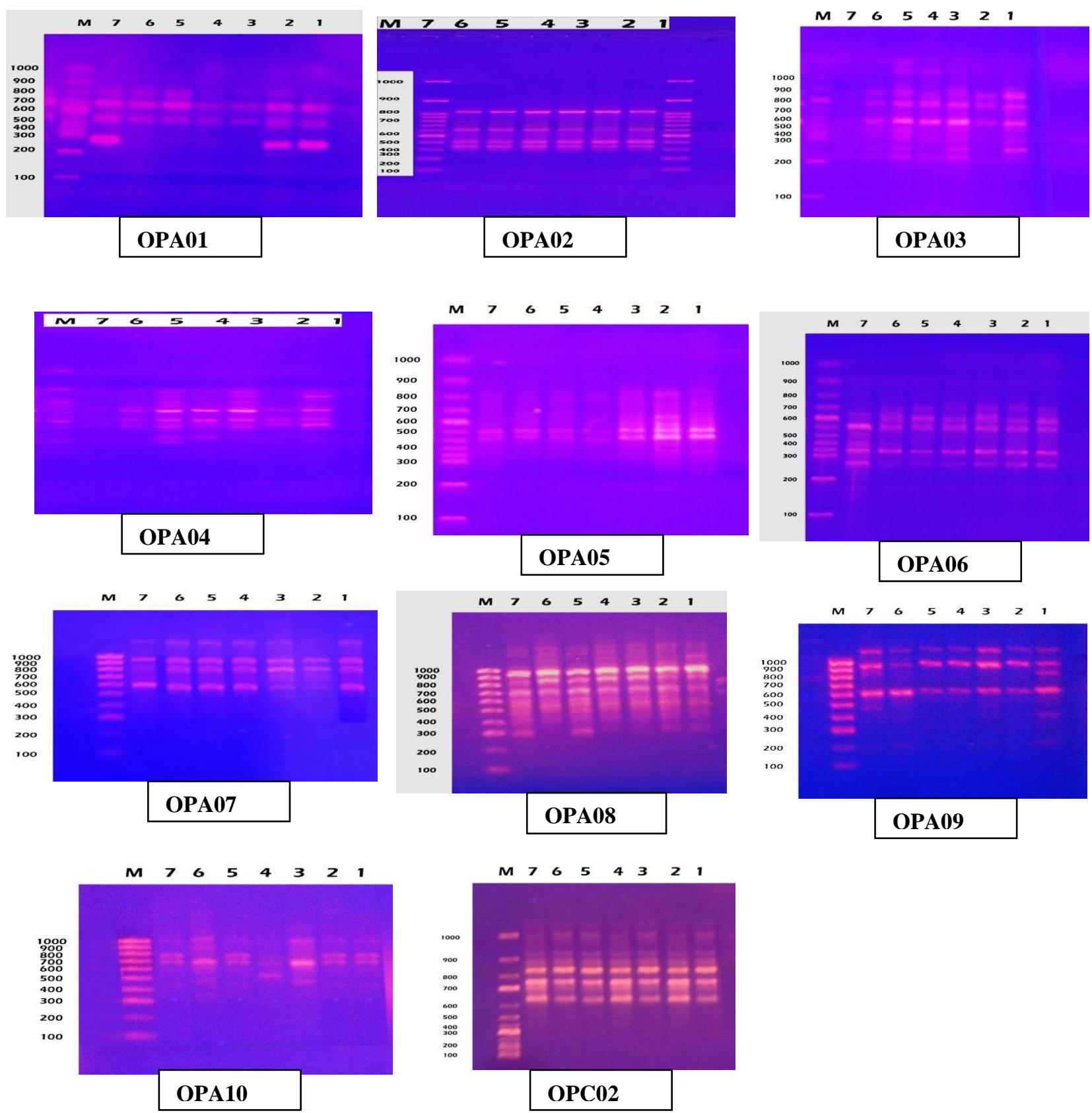

Figure 1 RAPD primer profiles amplified in C.officinalis genotypes.

Legend: $\mathrm{M}$, DNA ladder, and lanes from 1 to 7 represent $0.8 \%, 0.4 \%, 0.2 \%, 0.1 \%, 0.05 \%, 0.025 \%$ and $0.0 \%$ colchicine respectively.

\section{Evaluation of genetic diversity based on RAPD-PCR} Results of RAPD-PCR were applied to search out the differences between the vdisisponsearance of bands could be associate with changes or mutations of colchicine induc concentrations of colchicine in seedling stage. Phylogenetic relationships between diffsteptant DNA (Atienzar et al., 1999; Atienzar and Jha 2006). The high number concentrations of colchicine and existing genetic diversity were illustrated in tree dtisappeared bands was observed at 0.05 per cent concentration suggests that colchicine upon PCR results. The genetic diversity matrix was applied through NTSYS pe softwtriesfonncentration was able to induce DNA alterations that resulted in loss of band. cluster analysis. Genetic diversity assessment could be of great importance fapptaxance of new PCR bands may reveal a change in some oligonucletide priming due classification of genotypes, species and treatments. Estimating of genetic relationshipuatidons and juxtaposition two sequences that matching the primers sequence (Atienzar selecting of superior genotypes would be of great goals for selecting genotypes with hlghle99). RAPD has the potential to represent genetic differences in different ornamen desirable characters and improving plant breeding programs. Analysis of the dendrowgramip to species and cultivar levels (Kaul et al., 2011). SRAP marker technique was us showed high genetic diversity among genotypes, around 30\%. Phylogenetic tree repteseretify the existence of genetic variability at molecular-level as a result of the colchic two clusters; first cluster included only the control, while the second cluster divided intouttwengen concentrations (El-Nashar and Ammar 2016). Diethyl sulphate (DES) sub-clusters the higher doses in one and the reminder of genotypes in the other sub-Einstethyl sulphate (DMS) used in low concentrations and had a positive effects Figure (2). Data gathered from dendrogram illustrated the effect of treatment diversificationhological and yielding traits and genetic polymorphism among Calendula cultiv Various authors used the RAPD technique to detect the changes in DNA patterns medtited FISH-based visualization of 45S and 5S rDNA correlates with variability in calculate genetic similarity/diversity between genotypes/species. Genetic variationciltißar characteristics (Samatadze et al., 2019).

grandiflora using RAPD-PCR (Kumar et al., 2005) was studied because of the high level of RAPD polymorphism used to identify cultivars and the genetic variability was used to study genetic distances among genotypes and treated plants. The RAPD analysis was used in Dendranthema grandiflora cv. Snow Ball to detect genetic polymorphism among the mutants variants by mutagenesis in vitro (Kaul et al., 2011). Genetic diversity was estimated using RAPD (Zainudin et al., 2014) in Jatropha curcas mutants and in B. napus (Yassein and Aly 2014) and the results showed that genetic diversity can be calculated on the base of RAPD within the mutants. 


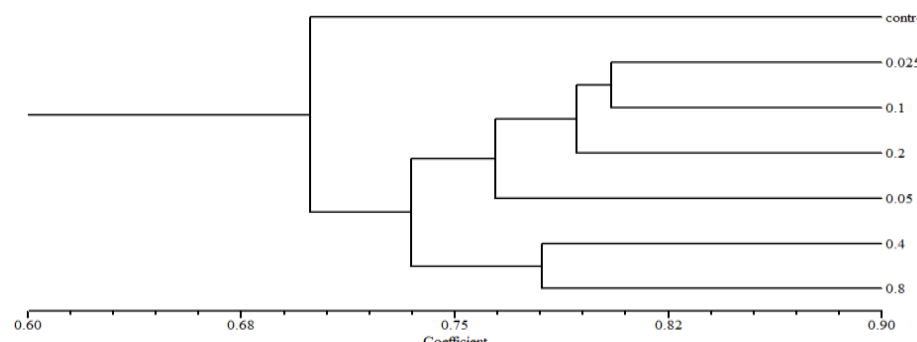

Figure 2 Dendrogram of C.officinalis genotypes induced by colchicine based on RAPD-PCR

\section{CONCLUSION}

Biodiversity. A. Karp, P.G. Isaac, and D.S. Ingram (eds.). Chapman \& Hall, London. 49-50.p.

Kaul, A., Kumar, S., Thakur, M., Ghani, M. (2011). Gamma Ray-Induced in Vitro Mutations in Flower Colour in Dendranthema grandiflora Tzelev. Floriculture and Ornamental Biotechnology, 5(1), 71-73.

Kharkwal, M.C. and Shu, Q.Y. (2009). The role of induced mutations in world food security. Q.Y. Shu (ed.), Induced Plant Mutations in the Genomics Era Food and Agriculture Organization of the United Nations, Rome, 2009, 33-38.

Kouchebagh, S.B., Rasouli, P., Babaiy, A.H., Reza, A. (2015). Seed germination of pot marigold (Calendula officinalis L .) as affected by physical priming techniques. International Journal of Biosciences, 6(5), 49-54 http://dx.doi.org/10.12692/ijb/6.5.49

Kumar, S., Prasad, K. V., Kumar, S., Chauhan, V. S., Choudhary, M.L. (2005) Genetic variability and relatedness among chrysanthemum cultivars based on RAPD. Indian Journal of Horticulture, 62, 370-374.

Kushwah, K.S., Verma, R.C., Patel, S., Jain, N.K. (2018). Colchicine Induced Polyploidy in Chrysanthemum carinatum L . Journal of Phylogenetics \& Results highlight the usefulness of colchicine application in Calendula induction muatibationary Biology, 6(1), 1-4. http://dx.doi.org/10.12692/ijb/6.5.49 and found high heritability in the majority of traits, which help in plant breeding progr\$hiłhaǐlovskiľ, S.S., Kulikov, A.M., Potapov, S.G., Lazebny̌̌, O.E., Mitrofanov, selection criteria. RAPD-PCR as a tool for detecting the effects of colchicine on Caldida2007). A RAPD fingerprinting of sibling species of the Drosophila virilis and could be used significantly in the detection of useful mutants. The latest could bgrbed Genetika, 43, 105-109. https://doi.org/10.1134/S1022795407010140 inbreeding programs to improve inflorescence yield and quality as well as in detingatra, A. and Rout, G.R. (2005). Identification and analysis of genetic per cent colchicine for efficient breeding Calendula mutation.

Conflict of interest: The authors declare that they have no conflict of interest.

\section{REFRENCES}

A.O.A.C. (1970). Official Method of Analysis XI Edn. Association of Official Analytical Chemists, Washington D. C.

Abdoli, M., Moieni, A. Naghdi Badi, H. (2013). Morphological, physiological, cytological and phytochemical studies in diploid and colchicine-induced tetraploid plants of Echinacea purpurea (L.). Acta Physiologiae Plantarum, 35, 2075-2083. http://dx.DOI 10.1007/s11738-013-1242-9

Amiri, S., Kazemitabaar, S., Ranjbar, G. Azadbakht, M. (2010). The effect of trifluralin and colchicine treatments on morphological characteristics of jimsonweed (Datura Stramonium L.). Trakia Journal of Scince, 8, 47-61.

Atienzar, F.A., Conradi, M., Evenden, A.J., Jha, A.N., Depledge, M.H. (1999) Qualitative assessment of genotoxicity using random-amplified polymorphic DNA: Comparison of genomic template stability with key fitness parameters in Daphnia magna exposed to benzo[a]pyrene. Environmental Toxicology and Chemistry, 18, 2275-2282. https://doi.org/10.1002/etc.5620181023

Atienzar, F.A. and Jha, A.N. (2006). The random amplified polymorphic DNA (RAPD) assay and related techniques applied to genotoxicity and carcinogenesis studies: A critical review. Mutation Research - Reviews in Mutation Research 613,76-102. https://doi.org/10.1016/j.mrrev.2006.06.001

Della-loggia, R., Tubaro, A., Sosa, S., and ... Isaac, D. (1994). The role of triperpenoids in the topical antiinflamatory activity of Calendula officinalis flowers. Planta Medica, 60, 516-520. https://doi.org/10.1055/s-2006-959562

Dellaporta, S.L., Wood, J., Hicks, J.B. (1983). A plant DNA minipreparation: Version II. Plant Molecular Biology Reporter, 1, 19-21.

Dubois, M., Gilles, K.A., Hamilton, P.A., Rebers, P.A., Smith, F. (1956) Colorimetric Method for Determination. Analytical Chemestiry, 28(3), 350-356. http://felix.ib.usp.br/pessoal/marcos/fisio2008/PDF/PDF PRATICA/dubois.pdf

Eberle, C.A., Forcella, F., Gesch, R., Peterson, D. Eklund, J. (2014). Seed germination of calendula in response to temperature. Industrial Crops and Products, 52, 199-204. https://doi.org/10.1016/j.indcrop.2013.10.031

El-Nashar, Y.I. and Ammar, M.H. (2016). Mutagenic influences of colchicine on phenological and molecular diversity of Calendula officinalis L. Genetics and Molecular Research, 15, 1-15. https://doi.org/10.4238/gmr.15027745

Eshghi, R., Abrahimpour, F., Ojaghi, J. Salayeva, S. (2012). Evaluation of genetic variability in naked barley (Hordeum vulgare L.). International Journal of Agriculture and Crop Sciences, 4, 1166-1179. https://doi.org/10.12692/ijb/5.4.108-116

Estaji, A., Hosseini, B., Ghotbi Ravandi, E., Dehghan, E., Sefidkon, F. (2017) The effects of colchicine-induced autotetraploidy on selected characteristics of nuruozak (Salvia leriifolia). Cytology and Genetics, 51, 74-81. https://doi.org/10.3103/S0095452717010042

Hannweg, K., Sippel, A., Bertling, I. (2013). A simple and effective method for the micropropagation and in vitro induction of polyploidy and the effect on floral characteristics of the South African iris, Crocosmia aurea. South African Journal of Botany, 88, 367-372. https://doi.org/10.1016/j.sajb.2013.09.005

Hassan, G.M. and Yassein, A.A.M. (2014). Cytogenotoxicity evaluation of water contami- nated with some textile azo dyes using rapd mark- ers and chromosomal aberrations of onion (Allium cepa) root cells. Egyptian Journal of Genetics and Cytology, 43, 39-57. https://doi.org/10.21608/ejgc.2014.9932

Herbert, W., Robinson, H.F., Comstock, R.E. (1955). Estimates of Genetic and Environmental Variability in Soybeans 1.1955 https://doi.org/10.2134/agronj1955.00021962004700070009x

Hyam, R. (1998). Field collection: Plants. In: Molecular Tools for Screening
Zeitschrift fur Naturforschung - Section C Journal of Biosciences, 60, 611-617. https://doi.org/10.1515/znc-2005-7-817

Nura, S., Adamu, A.K., Mu’ Azu, S., Dangora, D.B., Fagwalawa, L.D. (2013) Morphological characterization of colchicine-induced mutants in sesame (Sesamum indicum L.). Journal of Biological Science, 13, 277-282.

Pickens, K. A., Cheng, Z. M., Kania, S.A. (2006). Effect of colchicine and oryzalin on callus and adventitious shoot formation of (Euphorbia pulchurrima) "Winter Rose". Hort Science, 41, 1651-1655.

Rahim, M.A., Mia, A.A., Mahmud, F., Zeba, N., Afrin, K.S. (2010). Genetic variability, character association and genetic divergence in Mungbean (Vigna radiata L. Wilczek). Plant Omics, 3, 1-6.

Ramos, A., Edreira, A., Vizoso, A., Betancourt, J., Lopez, M., Decalo, M. (1988). Genotoxicity of an extract of Calendula officinalis L. Journal of Ethnopharmacol, 61, 9-55. https://doi.org/10.1016/s0378-8741(98)00017-8

Samatadze, T.E., Zoshchuk, S.A., Hazieva, F.M., and ... Muravenko, O. V. (2019). Phenotypic and molecular cytogenetic variability in calendula (Calendula officinalis L .) cultivars and mutant lines obtained via chemical mutagenesis. Scientific Reports, 1-11. https://doi.org/10.1038/s41598-019-45738-3

Sambrook, B.J., Maccallum, P., Russell, D. (2006). Molecular Cloning: A Laboratory Manual To order or request additional information: Molecular https://doi.org/10.1093/pcp/pcv186

Sano, N., Rajjou, L., North, H.M., Debeaujon, I., Marion-Poll, A., Seo, M (2016). Staying alive: Molecular aspects of seed longevity. Plant and Cell Physiology, 57, 660-674. https://doi.org/10.1093/pcp/pcv186

Soubra, N., Yazbek, M.M., Noun, J., and ... Karam, N. (2018). Evaluation of diversity and conservation status of Matricaria chamomilla (L.) and Matricaria aurea (Loefl.) Sch. Bip. in Lebanon. Journal of Biodiversity \& Endangered Species, 06, 1-10. https://doi.org/10.4172/2332-2543.1000206

Wang, L.J., Sheng, M.Y., Wen, P.C., Du, J.Y. (2017). Morphological, physiological, cytological and phytochemical studies in diploid and colchicineinduced tetraploid plants of Fagopyrum tataricum (L.) Gaertn. Botanical Studies 58. https://doi.org/10.1186/s40529-016-0157-3

Yassein, A.A.M. and Aly, A.A. (2014). Effect of gamma irradiation on morphological, physiological and molecular traits of Brassica napus. Egyptian

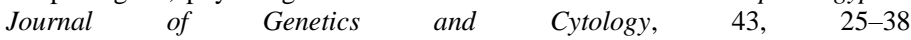
https://doi.org/10.21608/ejgc.2014.9931

Zainudin, A., Maftuchah, Fitriani, H. (2014). Analysis of genetic diversity on mutants Jatropha curcas using RAPD. Energy Procedia, 47, 1-6. https://doi.org/10.1016/j.egypro.2014.01.189

Zhang, Q., Zhang, F., Li, B., Zhang, L. Shi, H. (2016). Production of tetraploid plants of Trollius Chinensis Bunge induced by colchicine. Czech Journal of Genetics and Plant Breeding, 52, 34-38. https://doi.org/10.17221/89/2015CJGPB Cloning: A Laboratory Manual Third Edition. I: 1-3 